\title{
A DECISION-MAKING SUPPORT MODEL FOR ENTERPRISES LOCALIZATION STRATEGIES
}

\begin{abstract}
The knowledgeable of the features of a territory where an enterprise is intended to operate is - to any operator/entrepreneur - a primary need and a prerequisite for the implementation of any investment. The need to gather scientific and exhaustive information about a specific context and its real development opportunities is mandatory for any decision concerning business investment and location.

On the basis of these considerations, forecast and scenario operations have risen to a higher status since these tools help external observers understand a territory and its peculiar characteristics.

It is within this framework that this paper aims at describing a supporting model for the decision-making process that may steer the location decisions of international businesses. This is made possible by a measurement system where the characteristics of a territory are assessed with reference to some key factors that are internationally known to investors, to the aim of spotting the best location to implement a property investment.
\end{abstract}

\section{KEYWORDS}

Property investments, localization, strategic territorial marketing, real estate redevelopment, decision-making support model

\section{INTRODUCTION}

Regardless of their size, the urban areas and their relevant territories have become part of a competitive environment that has originated from the growing internationalization and globalization of the markets, of production systems and of the society. The effects of such changes unfold in the fierce competition among various metropolises to attract public and private investments, knowledge and brains, great shows and cultural events.

Given this economic context, two dimensions have grown so relevant that they are forcing even local systems to face their implications: the socio-economic attractiveness and the competitiveness of the local production fabric.

Generally speaking, competitiveness may be defined as the ability of the enterprises and of a territory to make the most of the factors made available to them (in terms of natural resources, physical capital, human capital, etc...). Therefore competitiveness has to do with the whole set of the factors making economic development possible from the inside, and from the outside as well. On the other hand, attractiveness may be defined as the ability of a specific economic system to attract and retain human and economic capital, favouring the localization of manufacturing activities. Attractiveness and competitiveness are therefore two highly complementary concepts, albeit not overlapping: the higher attractiveness of a territory favours the deployment of production activities and creates the preconditions for the development of competitiveness as well. Similarly, a territory becomes "competitive" when it is able to attract and retain those resources that guarantee profitable conditions to the economic players located on this same territory, as against their competitors on the international markets.

This triggers the so-called "virtuous circle" that is mentioned in the research work "Investimenti esteri in Italia" (Foreign investments in Italy) made in 2007 (Siemens, Ambrosetti, 2007).

To increase its competitiveness and attractiveness, an area should promote a territory proposal that meets the expectations of those (endogenous and exogenous) players whom the territory wishes to attract, since they may provide useful resources for its development. This is made possible by operating on those "attractiveness factors" that typically 
characterise a territory against its competing areas, and on the elements that shape the identity of the territory (Anholt, S., 2007).

"Identity" should be read, then, as the result achieved over time through different elements that converge on a sole image made of specific knowledge and competences, i.e. the real competitive advantage for the enterprises located on that territory; an image consisting in vocational-training proposals and quality of its human resources, in attractive elements that strongly differentiate its urban context and catalyse specific demand segments to the territory. But "identity" can be seen also as a complex set of socio-economic aspects and of shared values, lifestyles, consumption processes and relations.

Altogether these elements define the expediency of a geographical area over another; these however should not be evaluated according to their objective characteristics, but should be rather fused with the perceptions we gain from their characteristics. The relevance of these elements depends upon the subjective value that the potential investor attaches to them, based on the information and the direct and indirect experiences the investor has of them.

This picture highlights the relevance of forecast and scenario operations, which help an external observer understand a territory thanks to the strong attraction exerted by its diverse elements, and to the importance attached to the diverse territory proposals.

\section{THE ISSUES OF THE RESEARCH WORK}

Generally investors behave as the buyers of industrial goods do, and follow a logical decision-making thinking that generates a purely rational behaviour: every investor makes the decision to invest in a specific area only if they are convinced that the perspective to make a reasonable profit is more than likely (Di Savino, C., 2007).

More generally, the aspects that may influence the decision of an investor are both physical and immaterial. Among the physical factors worth mentioning are the morphological structure of the territory, the infrastructures for economic and social activities, the natural sources of the production factors, the governing bodies, the public institutions and the administrative organization, the production fabric and the financial system, the centres of knowledge, the human capital, the size and the quality of the market, and the concrete factors that determine the quality of life. Among the immaterial factors are the knowledge rooted in the territory - i.e. the unwritten knowledge - the level of the social capital, the reputation abroad, the degree of openness to innovation, the level of wellbeing and social cohesion meant as immaterial elements that define the quality of life.

Given these elements, attractiveness is becoming a priority topic that national politicians and local administrators have to face in a systematic manner and with a long-term strategy that addresses the targets to be achieved and the competitiveness of their territory.

The prerequisites for any entrepreneur's decision concerning investments and business location are the availability of scientific and complete information on the territory and its development opportunities; greater coordination with the local administrators and institutions that are in charge of planning and monitoring such development opportunities; and the possibility to gain information about the institutional programmes regarding the territory.

\section{CRITERIA AND LOGICS SUPPORTING THE CHOICE OF A BUSINESS LOCATION}

Among the decisive factors that steer the decision about a business location are the exogenous macro-variables that influence the attractiveness and the competitiveness of any territorial system globally, plus other basic factors that contribute to shaping the power to attract foreign investments.

Summing up, the decision about a location taken by any investor is generally conditioned by several factors, which can be grouped in two main categories: the characteristics of domestic institutions (by way of example, the current laws on labour, taxation on company revenue, the efficiency of bureaucracy or of the judicial system), and the local 
characteristics (the size of the labour market, the level of infrastructures and human capital, the cost of the production factors, investments in Research and Development) (Basile, R., Benfratello, L., Castellani ,D., 2008).

The Table I below summarises and discriminates the local (regional) characteristics from the institutional-domestic factors.

\section{Location factors}

\section{Indicators}

\section{Stage 1} (general location factors)

\begin{tabular}{|c|c|}
\hline $\begin{array}{l}\text { The market and the economic } \\
\text { system }\end{array}$ & $\begin{array}{l}\text { GDP, population, FDI flows, import-export, } \\
\text { unemployment rate }\end{array}$ \\
\hline System of taxation & Corporate tax, incentives \\
\hline Labour force & $\begin{array}{l}\text { Level of education of the population, labour regulations, } \\
\text { overall costs, productivity }\end{array}$ \\
\hline Innovation & $\begin{array}{l}\text { Expenditure in R\&D as GDP \%, size of the ICT market, } \\
\text { broadband diffusion }\end{array}$ \\
\hline Infrastructures & Availability of roads, railways, ports, and airports \\
\hline Socio-political frames & Political stability, degree of corruption, level o \\
\hline
\end{tabular}

Stage 2

The market and the economic Businesses operating in the same industry, network of system suppliers

Tax and financial system Availability of tax and financial incentives, presence of financial services (venture capital)

Regional/local level (location-specific factors)
Labour force employed in the reference industry, people with a degree in specific subjects, cost per each professional profile

Presence of specific R\&D centres and of their relevant projects/competences

Areas for settlement Characteristics of the sites, times and costs of the settlement

Table I: The stages of the localization process

Source: Data processing by Invest in Milan and Politecnico di Milano of the data provided by Financial Times FDI Intelligence

\section{THE KEY FACTORS FOR THE LOCALIZATION OF PROPERTY INVESTMENTS ACCORDING TO INTERNATIONAL STANDARDS}

Various industry-specific surveys have analysed this issue, and identified the international "key factors" for the choice of the location where an investment will be made.

Based on the report entitled European Cities Monitor 2012 (Cushman \& Wakefield, 2012), the four main elements that enterprises take into consideration when deciding on the location or the change of location of their business are, in order of importance: 
1. easy access to markets, customers and consumers;

2. availability of qualified staff;

3. quality of the telecommunications;

4. connections with other international cities.

On the contrary, the 2012 Growth, actually. European Attractiveness Survey (EAS) (Ernst\&Young, 2012) lists the following location factors first: access to the market (39\%) and stability and transparency of the political environment (36\%).

These factors are sided by social elements that may enhance the productivity of the country through research and innovation, as is the availability of qualified and skilled labour force (28\%).

On the other hand, the detrimental factors for the competitive advantage are too high costs of labour and manpower when compared to other emerging economies.

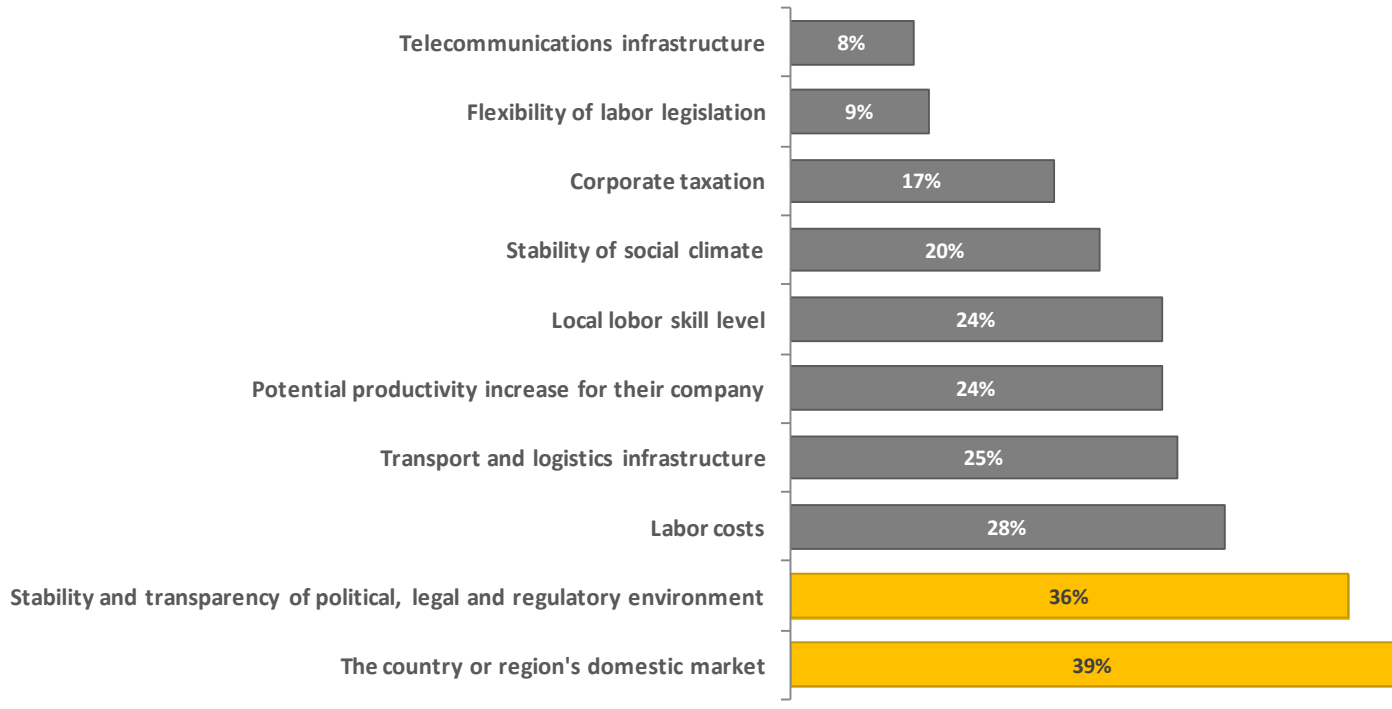

Figure 1: The main factors influencing the choice of the location of business investments

Source: Ernst \& Young "Growth, actually. European attractiveness survey" 2012.

\section{THE ATTRACTIVE POWER OF ITALY ON DOMESTIC AND INTERNATIONAL ENTERPRISES}

Although European countries now look less attractive than other emerging countries, mainly because of their rate of taxation (which is on average higher than in other countries), of the high public indebtedness and of the lack of a cohesive European government for political and economic issues, Europe still remains a much sought-for destination for the foreign investors who see a wealth of strengths in this continent. Among these worth mentioning are: diversified and high-quality workforce, high social responsibility, a favourable business environment, and the good proneness of the establishment to research and innovation. 


\begin{tabular}{|c|c|c|c|}
\hline \multicolumn{2}{|c|}{$\begin{array}{l}\text { Top five investing countries } \\
\text { by FDI projects ( } 2011 \text { ) }\end{array}$} & \multicolumn{2}{|l|}{ Top five sectors by FDI projects (2011) } \\
\hline \multicolumn{4}{|c|}{ UNITED KINGDOM } \\
\hline US & $42 \%$ & Business services & $24 \%$ \\
\hline Germany & $9 \%$ & Software & $22 \%$ \\
\hline India & $4 \%$ & Machinery and equipment & $6 \%$ \\
\hline France & $4 \%$ & Financial intermediation & $5 \%$ \\
\hline China & $3 \%$ & Food & $4 \%$ \\
\hline \multicolumn{4}{|l|}{ GERMANY } \\
\hline US & $21 \%$ & Business services & $15 \%$ \\
\hline Switzerland & $11 \%$ & Software & $11 \%$ \\
\hline UK & $9 \%$ & Machinery and equipment & $10 \%$ \\
\hline China & $8 \%$ & Electrical & $8 \%$ \\
\hline France & $6 \%$ & Electronics/automative components & $5 \%$ \\
\hline \multicolumn{4}{|l|}{ FRANCE } \\
\hline US & $23 \%$ & Business services & $16 \%$ \\
\hline Germany & $16 \%$ & Software & $11 \%$ \\
\hline UK & $13 \%$ & Machinery and equipment & $9 \%$ \\
\hline Switzerland & $11 \%$ & Financial intermediation & $6 \%$ \\
\hline Belgium & $7 \%$ & Other transport services & $5 \%$ \\
\hline \multicolumn{4}{|l|}{ SPAIN } \\
\hline US & $19 \%$ & Business services & $19 \%$ \\
\hline Germany & $14 \%$ & Software & $10 \%$ \\
\hline France & $13 \%$ & Food & $6 \%$ \\
\hline UK & $11 \%$ & Other transport services & $6 \%$ \\
\hline Netherlands & $7 \%$ & Machinery and equipment & $6 \%$ \\
\hline \multicolumn{4}{|c|}{ NETHERLANDS } \\
\hline US & $36 \%$ & Business services & $20 \%$ \\
\hline UK & $12 \%$ & Other transport services & $11 \%$ \\
\hline Japan & $8 \%$ & Chemicals & $6 \%$ \\
\hline Germany & $7 \%$ & Software & $6 \%$ \\
\hline France & $5 \%$ & Financial intermediation/food & $6 \%$ \\
\hline
\end{tabular}

\begin{tabular}{|c|c|c|c|}
\hline \multicolumn{2}{|c|}{$\begin{array}{l}\text { Top five investing countries } \\
\text { by FDI projects (2011) }\end{array}$} & \multicolumn{2}{|c|}{ Top five sectors by FDI projects (2011) } \\
\hline \multicolumn{4}{|l|}{ BELGIUM } \\
\hline US & $25 \%$ & Business services & $21 \%$ \\
\hline France & $11 \%$ & Other transport services & $9 \%$ \\
\hline UK & $9 \%$ & Software & $8 \%$ \\
\hline Germany & $7 \%$ & Chemicals & $7 \%$ \\
\hline Netherlands & $7 \%$ & Food & $7 \%$ \\
\hline \multicolumn{4}{|l|}{ RUSSIA } \\
\hline US & $18 \%$ & Food & $11 \%$ \\
\hline Germany & $11 \%$ & Machinery & $11 \%$ \\
\hline France & $7 \%$ & Automotive & $9 \%$ \\
\hline Netherlands & $5 \%$ & Business services & $9 \%$ \\
\hline Finland/Japan/Italy & $5 \%$ & Chemicals & $7 \%$ \\
\hline \multicolumn{4}{|l|}{ POLAND } \\
\hline US & $20 \%$ & Automotive & $11 \%$ \\
\hline Germany & $15 \%$ & Business services & $9 \%$ \\
\hline UK & $14 \%$ & Electronics & $9 \%$ \\
\hline France & $6 \%$ & Machinery and equipment & $9 \%$ \\
\hline South Korea & $6 \%$ & Food & $6 \%$ \\
\hline \multicolumn{4}{|l|}{ IRELAND } \\
\hline US & $64 \%$ & Software & $22 \%$ \\
\hline UK & $10,3 \%$ & Business services & $14 \%$ \\
\hline France & $7 \%$ & Pharmaceuticals & $10 \%$ \\
\hline Bermuda & $3 \%$ & Financial intermediation & $8 \%$ \\
\hline Germany & $3 \%$ & Scientific Instruments & $7 \%$ \\
\hline \multicolumn{4}{|l|}{ SWITZERLAND } \\
\hline US & $41 \%$ & Business services & $26 \%$ \\
\hline Germany & $13,0 \%$ & Software & $11 \%$ \\
\hline UK & $10 \%$ & Financial intermediation & $9 \%$ \\
\hline Japan & $5 \%$ & Chemicals & $6 \%$ \\
\hline China/France/India & $3 \%$ & Machinery and equipment & $5 \%$ \\
\hline
\end{tabular}

Table II: FDI (foreign direct investment) prospects for the European countries

Source: Ernst \& Young "Growth, actually. European attractiveness survey" 2012.

In this scenario, Italy is still characterised by a rather critical situation, especially with reference to incoming foreign investments. Despite a large domestic market and a reasonable cost of labour when compared to that of other industrialised countries, Italy still shows a low direct investment/GDP ratio. Whilst several international papers, first of all the one of the Economist Intelligence Unit, have reported improvement in the past 15 years, the ability of Italy to compete with other European countries in attracting investments is still lower.

\begin{tabular}{|c|c|c|c|c|c|c|}
\hline \multirow[b]{2}{*}{ Rank } & \multirow[b]{2}{*}{ Country } & \multicolumn{4}{|c|}{ Number of projects } & \multirow{2}{*}{$\begin{array}{c}\text { Number of jobs } \\
2011\end{array}$} \\
\hline & & 2010 & 2011 & $\begin{array}{l}\text { Change } \\
2010-2011\end{array}$ & $\begin{array}{c}\text { Share of FDI } \\
2011\end{array}$ & \\
\hline 1 & United Kingdom & 728 & 679 & $-7 \%$ & $17 \%$ & 29,888 \\
\hline 2 & Germany & 560 & 597 & $7 \%$ & $15 \%$ & 17,276 \\
\hline 3 & France & 562 & 540 & $-4 \%$ & $14 \%$ & 13,164 \\
\hline 4 & Spain & 169 & 273 & $62 \%$ & $7 \%$ & 9,205 \\
\hline 5 & Netherlands & 115 & 170 & $48 \%$ & $4 \%$ & 2,229 \\
\hline 6 & Belgium & 159 & 153 & $-4 \%$ & $4 \%$ & 3,599 \\
\hline 7 & Russia & 201 & 128 & $-36 \%$ & $3 \%$ & 8,362 \\
\hline 8 & Poland & 143 & 121 & $-15 \%$ & $3 \%$ & 7,838 \\
\hline 9 & Ireland & 114 & 106 & $-7 \%$ & $3 \%$ & 5,373 \\
\hline
\end{tabular}




\begin{tabular}{|r|l|r|r|r|r|r|}
\hline 10 & Switzerland & 90 & 99 & $10 \%$ & $3 \%$ & 1,546 \\
\hline & Other & 916 & 1.040 & $14 \%$ & $27 \%$ & 59,344 \\
\hline & TOTAL & 3.757 & 3.096 & $4 \%$ & $100 \%$ & 157,824 \\
\hline
\end{tabular}

Table III: Rank of the first 10 European countries that looked most attractive for FDI (foreign direct investments) in 2011

Source: Ernst \& Young "Growth, actually. European attractiveness survey" 2012.

The responsibility of such a situation is often ascribed to globalization, which allegedly took some countries like China, India or Brazil to the forefront of the international economic scene and therefore diverted the financial and intellectual flows away from Italy, because of the low cost of labour and of a high growth rate. Although there is no doubt that the barycentre of the world economy has shifted to new attraction areas in the past decade, it is also true that the member states of the European Union - Italy excepted - still attract investments and talents.

Moreover the fact that macroeconomic trends change rapidly should not go underestimated, so much so that the main competitive advantage of the former emerging economies is becoming rapidly eroded by now. The cost of labour is growing fast in those countries (in China it grew by $69 \%$ between 2005 and 2010) and some analysts predict that by 2015 the cost of labour will make no difference in the choice whether to locate a manufacturing facility in China, in the USA or in Europe.

Several aspects have influenced and are still influencing the competitiveness of Italy as a system in a negative manner, the first of all being the fact that Italy lags behind in many sectors, notably regulation/law making, the efficiency of the Public Administration ${ }^{1}$, the labour market, finance/credit, infrastructures, and research.

Several statistic surveys ${ }^{2}$ show that the attractive potential of Italy on Foreign Direct Investments (FDI) is basically higher than the FDI Italy actually attracts.

Other research works point to a "country-related factor" depressing FDI further, and which is common to all the regions of Italy, notably a little flexible labour legislation, high taxation on company profits, bureaucracy and an inefficient judicial system (Basile, R., Benfratello, L., Castellani, D., 2009).
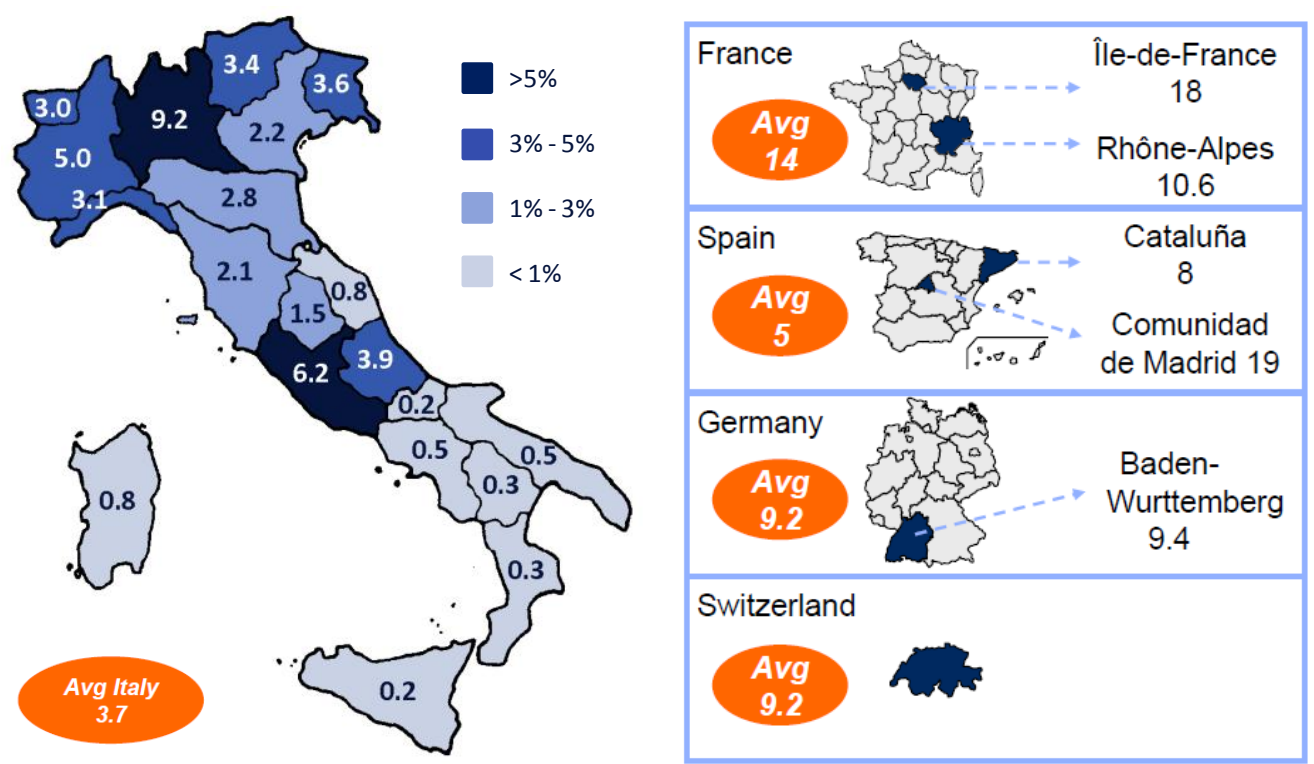

Figure 2: Distribution of foreign enterprises in Italy and in some European regions Source: Confindustria, 2010

\footnotetext{
1 The issue of the efficiency of the Public Administration in Italy is analysed in the yearly survey made by the Osservatorio Permanente della Pubblica Amministrazione Locale (OPPAL) of Politecnico di Milano, Dept. ABC - Gesti.Tec Laboratory

2 The statement that Italy attracts less FDI than its potential is also to be found in the World Investment Report of the United Nations (Unctad, 2004) where Italy - following a descriptive analysis, not a statistical one - is listed among the countries "below their potential", or countries with a low performance in terms of incoming FDI but with a high power of attraction, while all the greatest European countries are listed among the "front runners". The attraction potential is measured as the average value of a range of indicators including per-capita GDP, the growth rate of the economy, trade openness, ICT infrastructures, investment in R\&D, and the country risk.
} 
Today then, in the light of Italy's low performance in attracting foreign companies, the debate on the need to design a consistent policy to attract foreign investors is becoming pivotal in the wider framework of the industrial policies, in Italy as well (Basile R., Benfratello L., Castellani D., 2009).

All of the above further highlights the need to create adequate quantitative and qualitative tools that may constantly monitor the level of competitiveness of territorial economic systems, in order to timely and effectively implement all those interventions that are designed to preserve and strengthen the development conditions (Del Colle, E., 2006).

\section{THE MODEL}

So far no tools have been developed that may measure in an objective manner the attractive characteristics of a territory, i.e. the distinctive features of a territory that help enterprises steer their choices about a location. More specifically, there are no models dealing with this issue by using a universally known and shared language. Governments themselves have no tools that may enhance the effectiveness of those promotional activities addressed to enterprises and property investors and that have become mandatory in the globalized world.

The measurement system proposed in this paper is aimed at contributing to bridge this gap, albeit partially. This is a decision-making support tool that helps enterprises and property investors steer their choice of a site, by "measuring" the attractiveness of a territory with reference to the key factors analysed when an economic player wants to find the best location for a property investment.

This measurement system has a twofold purpose:

1. for enterprises: to simplify the direct comparison among areas having different attractiveness characteristics for potential investments;

2. for Public Administrations: getting to know the characteristics of the territory in order to understand which developments may enhance the potential and the attractive power of their territory.

\section{DESCRIPTION OF THE MODEL AND OF ITS KEY FACTORS}

The system proposed in this paper is based on the identification of the key factors that are internationally used by investors to derive the characteristics of the location of a property investment; and on the measurement of these factors through the specific indicators that show the agreement of the territory with the relevant key factors.

Based on national and international industry surveys ${ }^{3}$ on this topic, the following 12 key factors were identified:

- pro-business culture

- pro-business image and reputation

- access to the market

- basic infrastructures

- technological infrastructures

- availability and quality of the RE market

- skilled personnel

- human capital/talents

- Research \& Development

- educational/vocational training system

\footnotetext{
3 International industry surveys:

Cushman \& Wakefield, European Cities Monitor 2011;

Ernst \& Young, European Attractiveness Survey 2011;

GEM-Global Entrepreneurship, Monitor, Global Report 2010;

European Commission, Joint Research Centre EU, Regional Competitiveness Index 2010;

European Innovation Scoreboard (EIS) 2009, European Commission, Enterprise and Industry;

Scenari Immobiliari (2011), European Outlook 2012, "Ondone e ondine", September.

Local industry surveys:

Siemens Ambrosetti (2007), Investimenti esteri in Italia, Milano;

CERTeT Bocconi (2009), L'attrattività di Milano, Milano;

Unioncamere (2009), PIQ Rapporto nazionale;

IRER (2003), Studio sulle best practices di Marketing Territoriale e competitività del sistema lombardo 2003, Milano.
} 
- administrative, financial, judicial and taxation systems

- quality of life.

\section{Pro-business culture}

This expression denotes the culture of a Country and, more specifically, the pro-business aspects of that culture, or the culture of competitiveness with respect to rules and values. This cultural aspect plays a pivotal role in the "virtuous circle" of attractiveness, by stimulating all the other dimensions involved crosswise: by means of the attitudes and behaviours that favour business development, the pro-business culture allows the creation of the optimum conditions for a territory to look interesting to international investors, thereby conditioning their investment decisions in a positive manner.

\section{Pro-business image and reputation}

Among the key factors identified in the surveys and in several interviews with opinion leaders and decision-makers of international standing, the image and the pro-business reputation of a Country markedly influence, even irrationally, the choice of the countries where investments will be made.

\section{Access to the market and to customers}

This factor refers to the economic worth of the market in the area under examination, or to the size of quantitative demand (with reference to other markets), to the growth rate of the same, and to the average spending level of consumers.

A survey by Confindustria in 2011 reports that this factor is one of the most important determinants of businesses' location choices, especially in highly developed areas as the European Union, where the location strategies of multinationals are market-seeking mainly, rather than cost-reducing ${ }^{4}$.

The sales potential of a market is further influenced by the amount and the size of the competitors operating therein, or which might start their activity there with no special difficulties. The distribution of demand over the territory influences, in a permanent manner, the distribution of enterprises on the territory.

\section{Basic infrastructures}

The basic infrastructures (roads, motorways, railways, ports and airports) $)^{5}$ may be seen as the prerequisite for any investment, at any geographical latitude.

The presence of adequate infrastructures on a territory system is a necessary condition for the competitiveness of the territory itself, and an element that is highly appreciated by enterprises when making a choice about a new site.

\section{Technological infrastructures}

Side by side with basic infrastructures, technological infrastructures strongly impact on the attractiveness of an area. Technology favours the development of a country in high-potential sectors, and defines their development path.

\section{Quality of the RE sector}

The construction industry is more and more characterised by the performance-based approach, which has changed the property market progressively. If in the past the RE sector was a mass market, it is now turning more selective since the final users now make their choices based on the quality of the construction product. The development of these practices and the gradual growth of vertical sectors, with buildings having more and more complex technologies and systems ${ }^{6}$, have contributed to stimulating the demand for buildings of a higher quality that is less linked to aesthetic criteria, but rather oriented to a performance-based approach in order to meet the requirements of the potential target customers.

\footnotetext{
${ }^{4}$ The presence and the expansion on new markets, and/or the widening of a business' market by means of M\&A operations (Merger \& Acquisition) are the main strategic objectives that guide the location choices of multinationals.

${ }^{5}$ The comparison of the infrastructural heritage of Italy and the same heritage of its major European partners (France, Germany, Spain, and the United Kingdom) reveals a general unsuitability and obsolescence of the networks in our country. ANCE - Direzione Affari Economici e Centro Studi (edited by) (2009), Secondo Rapporto sulle infrastrutture in Italia 2009, 1st edition, May 29

${ }^{6}$ Office buildings, shopping malls, hotels, logistic platforms, etc.
} 


\section{Skilled personnel and cost of labour}

All the aspects related to labour contribute to determining the choice of the location of an investment, so much so that labour is assigned great relevance both theoretically and operationally (Caroli, 2001).

Among the labour-related aspects, the size of the supply is the one that differentiates the various geographical areas the most: given the same conditions, a wider supply of workforce determines a wider range of specializations, a reserve of manpower for cyclical or seasonal activities, and a shift of the contracting power in favour of the demand side. A wide supply of workforce may then become a strong attractive element for a territory (Coughlin, C. C., Terza, J. V, Aromdee, V., 1991) ${ }^{7}$ but this is not the only aspect that was taken into consideration. Besides the quantity of the available workforce, three additional conditions require evaluating that are particularly relevant when assessing the attractiveness of an area as the site of investments in production assets: cost, productivity, and level of competences.

\section{Human capital/talents}

When it comes to choosing an investment or a location, enterprises - and the large multinationals in particular - give much importance to the ability of a territory to offer an "attractive" climate that is favourable for the development of personal talent. The American economist Richard Florida (Florida, R., 2004) believes that talent is one of the preconditions for growth: when talents flow into a community, this means that various conditions and characteristics exist whereby creativity can freely produce and generate welfare. He believes that in order to aspire to compete on the international arena, players should favour the development of a "city of creative people"; to do so, a number of requisites must be put into place to exert a certain degree of attraction on this emerging class.

The factors forming the base of the attraction exerted by a city on the so-called new talents reside in the presence of a critical mass that can nurse and support this development (i.e. culturally lively settings that are open and tolerant and that establish productive networks of cultural exchange and partnership with similar groups within the same city) on the one hand; and in the cost of living in the same city, with particular reference to the cost of rents for housing, on the other.

\section{Research \& Development}

Expenditure in R\&D is the most traditional indicator used to describe the technological and scientific level of a production system; it is not by chance that it is generally used to gather indications on the ability of the system itself to generate, use and reproduce scientific and technological knowledge. This indicator is of fundamental importance in determining the levels of competitiveness when technological innovation, and more importantly technology transfer and implementation in the local production facilities provide the decisive boost to the whole economic fabric of the territory, affecting the relevant competitiveness levels among the various areas more sensibly and rapidly than the past.

\section{Administrative, financial, judicial and taxation systems}

The quality of the administrative, financial, judicial and taxation systems may weigh heavily upon the decision whether to invest in a specific territory or not.

A useful indicator in clarifying these aspects is to be found in the conditions for the start-up of a new enterprise/business. Favouring the start-up of an enterprise, or creating the favourable conditions for entrepreneurial dynamism and for capital investment, is one of the aspects that may positively influence the development of a country or of a territory.

\section{Educational/vocational training system}

Today the competition among territorial systems rests on knowledge: if institutions are called upon to favour the development of technical and civic notions, enterprises should enter this system of knowledge generation and strengthening by acting on the front line. Among the targets of higher education, one should be that of training young people for the world of labour and for competition.

\footnotetext{
${ }^{7}$ An empirical study made in 1991 in the United States already showed a positive correlation between the incoming of foreign enterprises to a specific geographical area, and the unemployment rate in the same area.
} 
A factor highly appreciated by the enterprises that decide to settle in a specific territory is exactly the effectiveness of the educational and vocational-training system and what it may offer, especially with reference to the requirements of the production system itself.

\section{Quality of life}

The quality of life meant as the social and economic welfare of a community, is a highly topical and inter-disciplinary issue in economic, social, political and town-planning analyses. If a town has a good quality of life, the majority of its population may benefit from a range of favourable conditions that may develop its human capital and stimulate the economic, social and cultural growth of the community.

The issue of quality as a development model has gradually rooted as the European countries were realizing that their competitive gap vis-à-vis the Anglo-Saxon economies was not so much linked to the higher or lower "maturity" of the reference supply chains, but rather to their ability to manage them so as to favour their evolution, without threatening the overall levels of economic, social and environmental sustainability.

\section{THE VALUATION METHOD}

The model herein proposed assesses and measures each key factor by the comparative method applied to the data and the figures concerning larger territories, which serve as a reference benchmark.

The compared territories vary depending upon the availability and quality of the data; some key factors produce meaningful results only if the territory is set in a wider context.

In the measurement system proposed in this paper, the comparison was made according to the table below, which summarises the relations existing among the different territorial scales that are compared to the reference territories, or benchmarks.

\begin{tabular}{|c|c|c|c|c|c|}
\hline & \multicolumn{4}{|c|}{ TERRITORY/BENCHMARK } \\
\hline & & District-level scale & $\begin{array}{l}\text { Regional-level } \\
\text { scale }\end{array}$ & National-level scale & $\begin{array}{c}\text { International-level } \\
\text { scale }\end{array}$ \\
\hline \multirow{3}{*}{ 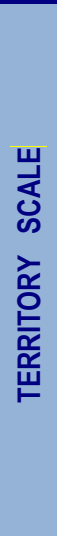 } & $\begin{array}{l}\text { Local territory } \\
\text { scale }\end{array}$ & $\begin{array}{l}\text { Availability and quality of } \\
\text { the RE market }\end{array}$ & Pro-business culture & $\begin{array}{l}\text { Access to the market; } \\
\text { technological } \\
\text { infrastructures; } \\
\text { Quality of life }\end{array}$ & \\
\hline & $\begin{array}{l}\text { District territory } \\
\text { scale }\end{array}$ & & $\begin{array}{l}\text { Administrative and financial } \\
\text { system }\end{array}$ & - Skilled personnel & $\begin{array}{l}\text { - Pro-business image } \\
\text { and reputation; } \\
\text { - Basic infrastructures }\end{array}$ \\
\hline & $\begin{array}{l}\text { Regional territory } \\
\text { scale }\end{array}$ & & & $\begin{array}{l}\text { - Pro-business image and } \\
\text { reputation; } \\
\text { - } \text { Human capital/talents; } \\
\text { - } \text { Research \& Development; } \\
\text { - Education and vocational } \\
\text { training system }\end{array}$ & \\
\hline
\end{tabular}

Table IV: Relations among the different territorial scales and the benchmarks for the assessment of the indicators pertaining to the key factors

\section{AIM OF THE MODEL}

The system has no limits concerning the size of the territories it can be applied to. However the smaller the scale, and the smaller the size of the area under examination, the more effective the measurement system.

The fact that a specific area is compared to a wider territory offers the possibility of making further and necessary considerations. Actually some wider-scale key factors (access to the market, educational/vocational training system, etc.) are not necessarily influenced by the resizing of the territorial framework: they refer to a context that goes beyond the 
borders of the area and of the municipality, to embrace the whole district and, sometimes, even metropolitan, regional or national contexts. On the other hand other factors (namely basic infrastructures, the quality of life, the town-planning and infrastructural features of the area, etc.) are more heavily influenced by local peculiarities that, if taken into consideration, enhance the effectiveness of the tool that measures attractiveness.

In this case the figures related to the indicators may be implemented and linked to a range of further indicators that depict the area under examination in a more specific manner.

The measurement tool herein proposed may therefore be made even more effective when the subjects of the measurement are the estates/properties available for investment allocation.

\section{THE INDICATORS IDENTIFIED BY THE MODEL TO CALCULATE THE SUMMARY INDEX OF THE KEY FACTORS}

In order to define the summary measurement index of the individual key factors, i.e. the score allocated to each, we need first to identify and measure the specific indicators that are deemed representative of the respondency of the territory with the relevant key factor under evaluation.

Since this method can be applied to areas of any size and on different scales, down to a specific development area, the list of the indicators pertaining to a single key factor will change depending on the size and the characteristics of the area under examination.

By way of example, below is the list of the indicators that are typical of a district-scale territory.

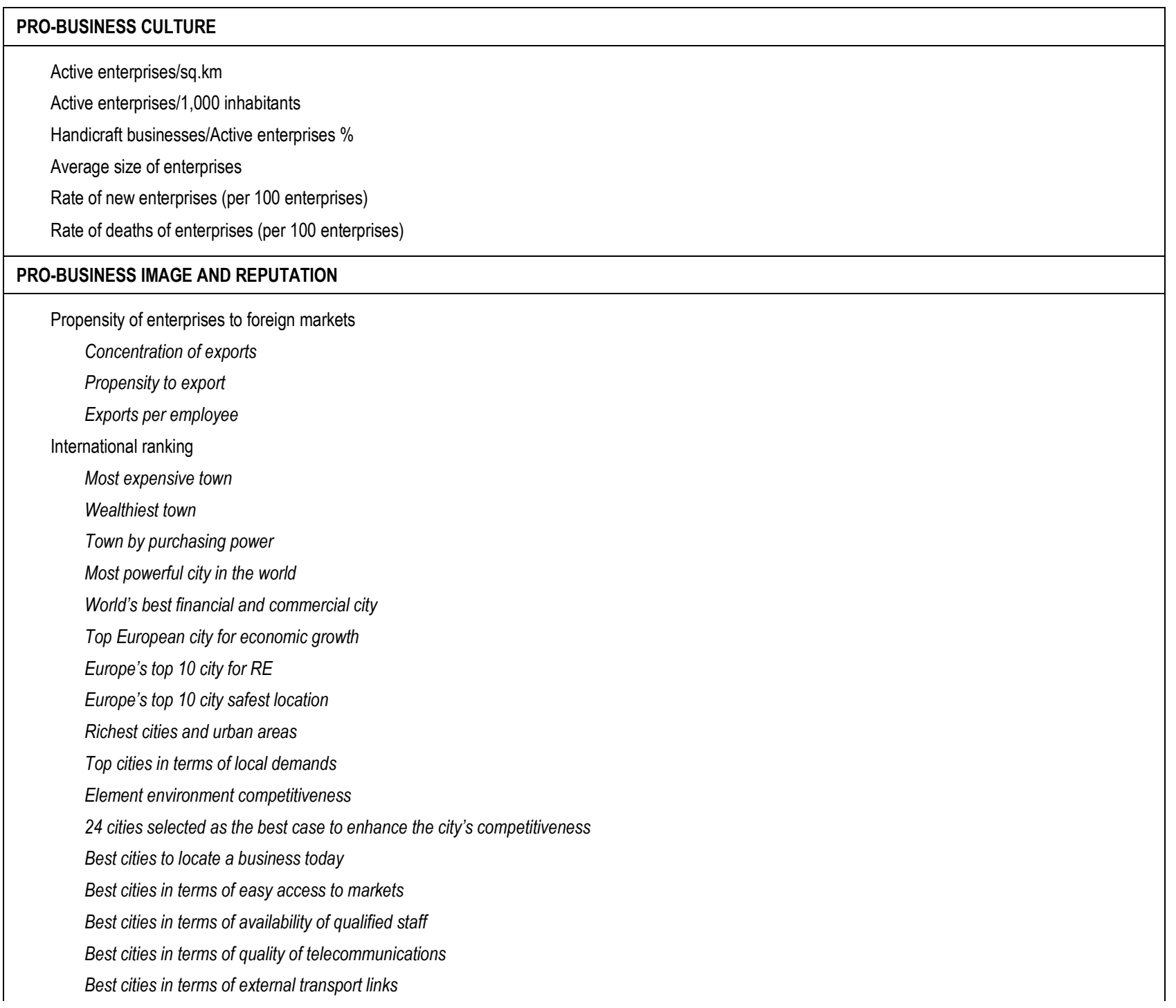


Best cities in terms of value for money of office space

Best cities in terms of cost of staff

Best cities in terms of availability of office space

Best cities in terms of the quality of life for employees

\section{ACCESS TO THE MARKET}

Per-capita GDP

Average income declared per inhabitant

Domestic final consumption, per capita ${ }^{8}$

Household expenditure on "Leisure time and culture" out of the overall consumption

Index of trade openness ${ }^{9}$

\section{BASIC INFRASTRUCTURES}

Index of allocation of the road network (Italy = 100)

Index of allocation of the railway network (Italy = 100)

Index of allocation of airports (and catchment areas) (Italy $=100$ )

General index of the economic infrastructures (Italy $=100)(3)$

General index of the social infrastructures (Italy $=100)(4)$

Index of access to intercontinental airborne traffic (London $=100$ )

Index of access to continental airborne traffic (London $=100$ )

Index of access to low-cost airborne traffic (London =100)

Index of access to cargo traffic (Frankfurt $=100$ )

\section{TECHNOLOGICAL INFRASTRUCTURES}

Index of allocation of telephony and telematics facilities and networks (Italy $=100$ )

Index of allocation of banking networks and various services (Italy $=100$ )

Population/bank counters

Bank loans per clientele localization, per inhabitant

Bank loans per localization of bank counters, per inhabitant

Bank deposits per clientele localization, per inhabitant

Bank deposits per localization of bank counters, per inhabitant

Index of dissemination of the broadband in enterprises

\section{HUMAN CAPITAL/TALENTS}

$\%$ of employees in R\&D - public agencies (2008)/labour force aged 15-64

$\%$ of employees in R\&D - not-for-profit private institutions (2008)/labour force aged 15-64

$\%$ of employees in R\&D - enterprises(2008)/labour force aged 15-64

$\%$ of employees in R\&D - Universities(2008)/labour force aged 15-64

\section{RESEARCH \& DEVELOPMENT}

$\%$ of expenditure in in-house R\&D - public agencies (2008)/GDP

$\%$ of expenditure in in-house R\&D - not-for-profit private institutions (2008)/GDP

$\%$ of expenditure in in-house R\&D - enterprises (2008)/GDP

$\%$ of expenditure in in-house R\&D - universities (2008)/GDP

$\%$ of employees in R\&D - public agencies (2008)/labour force aged 15-64

$\%$ of employees in R\&D - not-for-profit private institutions (2008)/labour force aged 15-64

$\%$ of employees in R\&D - enterprises(2008)/labour force aged 15-64

$\%$ of employees in R\&D - Universities(2008)/labour force aged 15-64

R\&D expenditure of public and private enterprises as against the GDP (\%)

R\&D expenditure of public and private enterprises with reference to overall expenditure in Italy

No. of patents deposited by inventors

${ }^{8}$ Final, domestic per-capita consumptions are the expenditure allocated to the purchase of goods and services by both people residing permanently, and those temporarily living in an area.

${ }^{9}$ Percentage ratio between the sum of the exports and imports and the value of production. 
No. of patents for which at least one inventor resides in the Lombardy region

No. of patents deposited by applicants

No. of patents for which at least one applicant resides in the Lombardy region

\section{EDUCATIONAL/NOCATIONAL TRAINING SYSTEM}

Level of education of the population

Population aged $>15$ with primary school education - Percentage

Population aged $>15$ with secondary school education - Percentage

Population aged $>15$ with high-school diploma achieved after 2-3 years of study - Percentage

Population aged $>15$ with high-school diploma achieved after 4-5 years of study - Percentage

Population aged > 15 with Bachelor's degree, master's degree, PhD - Percentage (2010)

High-school education rate

ADMINISTRATIVE, FINANCIAL, JUDICIAL AND TAXATION SYSTEMS

Bad debts / bank loans for ordinary clients *100

Ranking of the efficiency of loan-granting procedures

QUALITY OF LIFE

Quality of life indicators (Milan)

Standard of living (Milan)

Services, Environment and Health

Business and Jobs

Law and order

Population

Leisure time

No. of ordinary beds in public and private hospitals per 1,000 inhabitants

No. of ordinary beds in private nursing homes per 1,000 inhabitants

International ranking

Quality of life offered to the people moving to town

Table V: List of the indicators that are typical of a territory on the district scale.

Source: Data processed by the author.

In order to identify the variables for the calculation of the summary index of the key factors per individual development area, four key factors were identified (namely basic infrastructures, technological infrastructures, availability and quality of the RE market, and quality of life) which require further and more specific indicators than the indicators usually applied to measure the attractiveness of a wider territory. For each of these factors, further and specific indicators can be defined that account for the typical features of the area (Table VI).

\section{BASIC INFRASTRUCTURES}

\section{Airport connections}

Travelling time to the airport of Linate

by car

by public transportation means

Travelling time to the airport of Malpensa

by car

by public transportation means

Low-cost airport connections

Travelling time to the airport of Linate

by car

by public transportation means

Travelling time to the airport of Orio al Serio

by car

by public transportation means

Railway connections 
Distance from the closest railway station

Direct connections with other towns in Lombardy from the closest railway station

\section{Road connections}

Travelling time to the closest motorway tollbooth

\section{Public transportation means}

Travelling time to the closest bus station

Direct connections with other towns in Lombardy from the closest bus stop

$$
\begin{aligned}
& \text { number of bus lines } \\
& \text { number of lines taking to Milan }
\end{aligned}
$$

Direct connection with the Milan underground

Connection with the Central Railway Station of Milan - interchange hub

$$
\begin{aligned}
& \text { by train } \\
& \text { by car }
\end{aligned}
$$

\section{TECHNOLOGICAL INFRASTRUCTURES}

\section{Presence or absence of the broadband}

\section{Travelling time to the Technology Parks}

Travelling time to the Polo Tecnologico di Vimercate

Travelling time to the Polo Tecnologico della Brianza

Travelling time to the Green \& High Tech District

\section{Availability of tourist-accommodation facilities}

\section{Travelling time to the Exhibition Centre of Fiera Rho}

by car

by public transportation means

\section{AVAILABILITY AND QUALITY OF THE RE MARKET}

\section{Property values}

Value of new flats

Housing (average) €/sq.m

Trade $€ /$ sq.m (north and Groane, north of Milan, area of Rho)

Recent office buildings $€ /$ sq.m (north and Groane, north of Milan, area of Rho)

New industrial warehouses $€ /$ sq.m

Industrial warehouses older than 20 years $€ /$ sq.m

Lock-up garages (€ per unit)

Plots of land for housing development $€ /$ sq.m

Rent of a flat larger than 70 sq.m, not furnished, $€ /$ sq.m./year

Rent of furnished studio apartment/two-roomed flat $€ /$ sq.m/year

Rent of trade unit $€ /$ sq.m/year

Office rent $€ /$ sq.m/year

Industrial warehouse rent $€ /$ sq.m/year

\section{Charges for primary urbanization works}

Charges for primary urbanization works (housing) - new building

Charges for primary urbanization works (industry) - new building

Charges for primary urbanization works (craft activities) - new building

Charges for primary urbanization works (trade) - new building

Charges for primary urbanization works (offices) - new building

Charges for primary urbanization works (housing) - renovation

\section{Charges for secondary urbanization works}

Charges for secondary urbanization works (housing) - new building

Charges for secondary urbanization works (industry) - new building

Charges for secondary urbanization works (craft activities) - new building

Charges for secondary urbanization works (offices/trade facilities) - new building

Charges for secondary urbanization works (housing) - renovation

Characteristics of the buildings in the area

Degree of urban redevelopment, if any

\section{QUALITY OF LIFE}

Travelling distance from the closest hospital (Ospedale di Monza)

Closeness to parks of national appeal 


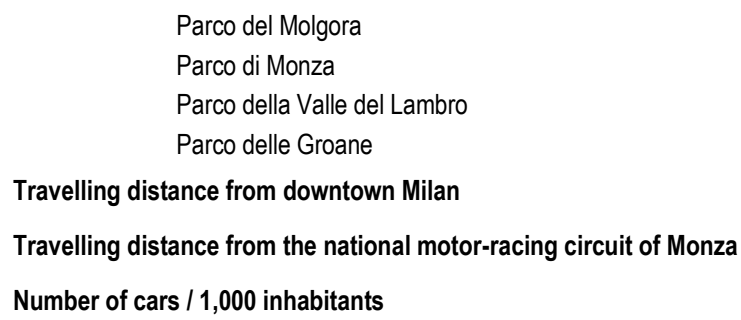

Table Vl: List of the specific indicators that are deemed to represent a development area with reference to the four main key factors Source: Data processed by the author.

The measurement score is given on a scale ranging from 0 (lowest score) to 5 (highest score), where a score of 3 is the average value that is in line with the benchmarks. The mean value of the scores assigned to the individual indicators that make up the relevant key factor corresponds to the overall score achieved for the key factor itself, or the "summary measurement index" of that specific key factor.

The comparison required to assign a score follows the relations existing among the different territory scales that are compared among themselves with reference to the various key factors.

\section{THE REPORTS OF THE MODEL}

The results obtained after applying the model are represented in an incisive manner by two representation systems:

- the OVERVIEW RADIAL DIAGRAMS OF THE AREA summarise graphically the 12 key factors of the areas under examination and show at the same time:

a. the direct comparison between the area of the survey and the wider territory benchmark. More specifically, the comparison highlights the "driving" factors and the "braking" ones with reference to the wider benchmark context;

b. the difference (in numerical terms) of the score given to the individual factor with reference to the two different contexts;

- the OVERVIEW BAR CHARTS OF THE INDICATORS, or the graphical representation of the score given to each factor, which compare directly the specific scores given to the individual indicators to the aim of identifying the weight of every individual indicator with reference to the overall score given to the higher-tier factor the indicator refers to.

\section{APPLICATION OF THE MODEL}

The model was tested on three areas in the district of Monza and Brianza, which are deemed ready to receive investments since they offer some buildings with an obsolete destination of use and for which the relevant public administration agency (the Provincial Government of Monza and Brianza) intends to find a new destination of use.

The areas spotted for the application of the analysis of attractiveness are all located in the District of Monza and Brianza and once were hospital facilities, now dismissed: the former hospital of San Gerardo in Monza, the former public hospital of Vimercate, and the former psychiatric hospital of Limbiate.

Here below is the application of the model on the area of the former psychiatric hospital of Limbiate, a health-care facility that has not been used for over 30 years now: its pavilions are in an abandoned state characterised by obsolescence and architectural degradation. 


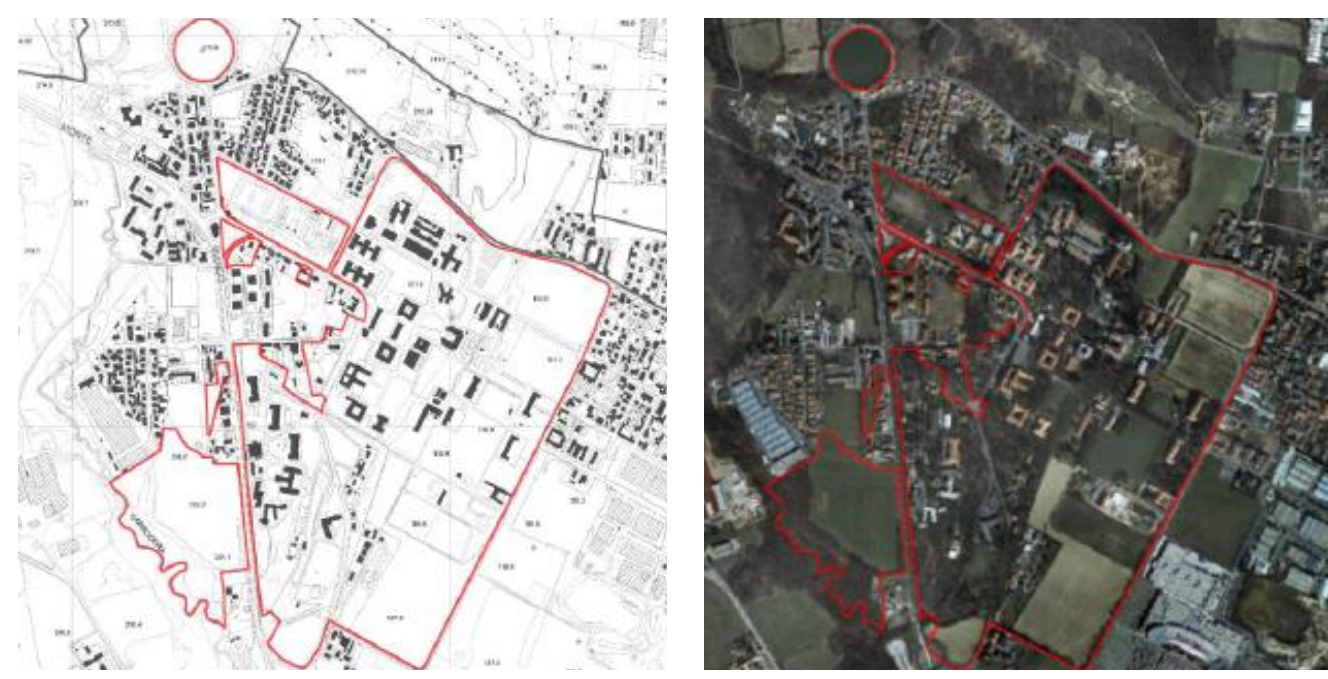

Figure 3: Boundaries of the area of Limbiate, a former psychiatric hospital Source: Provincial Government of Monza and Brianza

\begin{tabular}{|c|c|}
\hline $\begin{array}{l}\text { Profile of Area } \\
\text { A_3 }\end{array}$ & $\begin{array}{l}\text { Redevelopment target } \\
\text { FORMER PSYCHIATRIC HOSPITAL }\end{array}$ \\
\hline \multicolumn{2}{|l|}{ LOCATION } \\
\hline Address & Via Monte Grappa 19 \\
\hline Municipality & Limbiate \\
\hline \multicolumn{2}{|c|}{ FIGURES ABOUT THE MUNICIPALITY } \\
\hline Inhabitants & 35.168 \\
\hline Accessibility & Reasonable \\
\hline $\begin{array}{l}\text { Infrastructural and technological } \\
\text { endowment }\end{array}$ & Reasonable \\
\hline Broadband & Yes \\
\hline \multicolumn{2}{|l|}{ STATUS QUO } \\
\hline Type of ownership & $\begin{array}{l}\text { Public - Owned by the Health Board ASL of Monza and Brianza, by the District of Monza and Brianza, } \\
\text { and by the Hospital of Savini Garbagnate Milanese }\end{array}$ \\
\hline FLOOR AREA & 605,088 sq.m \\
\hline COVERED FLOOR AREA & 120,000 sq.m \\
\hline SIZE & $\begin{array}{l}\text { Now empty structure made up of pavilions in a state of considerable decay. Presence of historical } \\
\text { architectural structures subject to law restrictions }\end{array}$ \\
\hline STATE OF CONSERVATION & Conditions of appreciable architectural and environmental degradation \\
\hline DESTINATION OF USE & Psychiatric Hospital - Services and Facilities \\
\hline \multicolumn{2}{|l|}{ TOWN-PLANNING FORECASTS } \\
\hline Max GFA & Negotiable \\
\hline PRESENCE OF RESTRICTIONS & Fine Arts restriction in compliance with Art. 10 of leg. decree 42/2004 \\
\hline
\end{tabular}

Table VII: Figures about the area of Limbiate, a former psychiatric hospital Source: Provincial Government of Monza and Brianza 


\section{OVERVIEW RADIAL DIAGRAM}

The area of the former psychiatric hospital of Limbiate is an abandoned site in the district of Monza and Brianza, which covers an overall surface of nearly 605,000 sq.m with a covered floor area of 120,000 sq.m. The site is located north of the municipality of Limbiate, within a fairly developed urban context crossed by a road linking Limbiate to a major road. Being this a specific area, albeit of a considerable size, scores were given taking into consideration both the general factors related to the district territory, and the area-specific factors (Table VIII).

\begin{tabular}{l|l|l} 
& $\begin{array}{c}\text { Area of the former psychiatric } \\
\text { Hospital - Limbiate }\end{array}$ & $\begin{array}{c}\text { Provincial } \\
\text { government of MB }\end{array}$ \\
\hline Pro-business culture & 4.08 & 4.08 \\
\hline Pro-business image and reputation & 3.76 & 3.76 \\
\hline Access to the market & 4.40 & 4.40 \\
\hline Basic infrastructures & 2.64 & 2.67 \\
\hline Technological infrastructures & 3.04 & 3.56 \\
\hline Availability and quality of the RE market & 2.60 & 3.20 \\
\hline Skilled personnel & 2.38 & 2.38 \\
\hline Human capital/talents & 3.25 & 3.25 \\
\hline Research \& Development & 3.68 & 3.68 \\
\hline Educational and vocational training system & 4.20 & 4.20 \\
\hline Administrative, financial, judicial and taxation systems & 2.25 & 2.25 \\
\hline Quality of life & 3.35 & 3.75 \\
\hline
\end{tabular}

Table VIII: The scores given to the 12 key factors for the Limbiate area, former psychiatric hospital

The overview radial diagram clearly shows the "driving" key factors and the "braking" key factors in this area, compared to the wider context of the district of Monza and Brianza. 


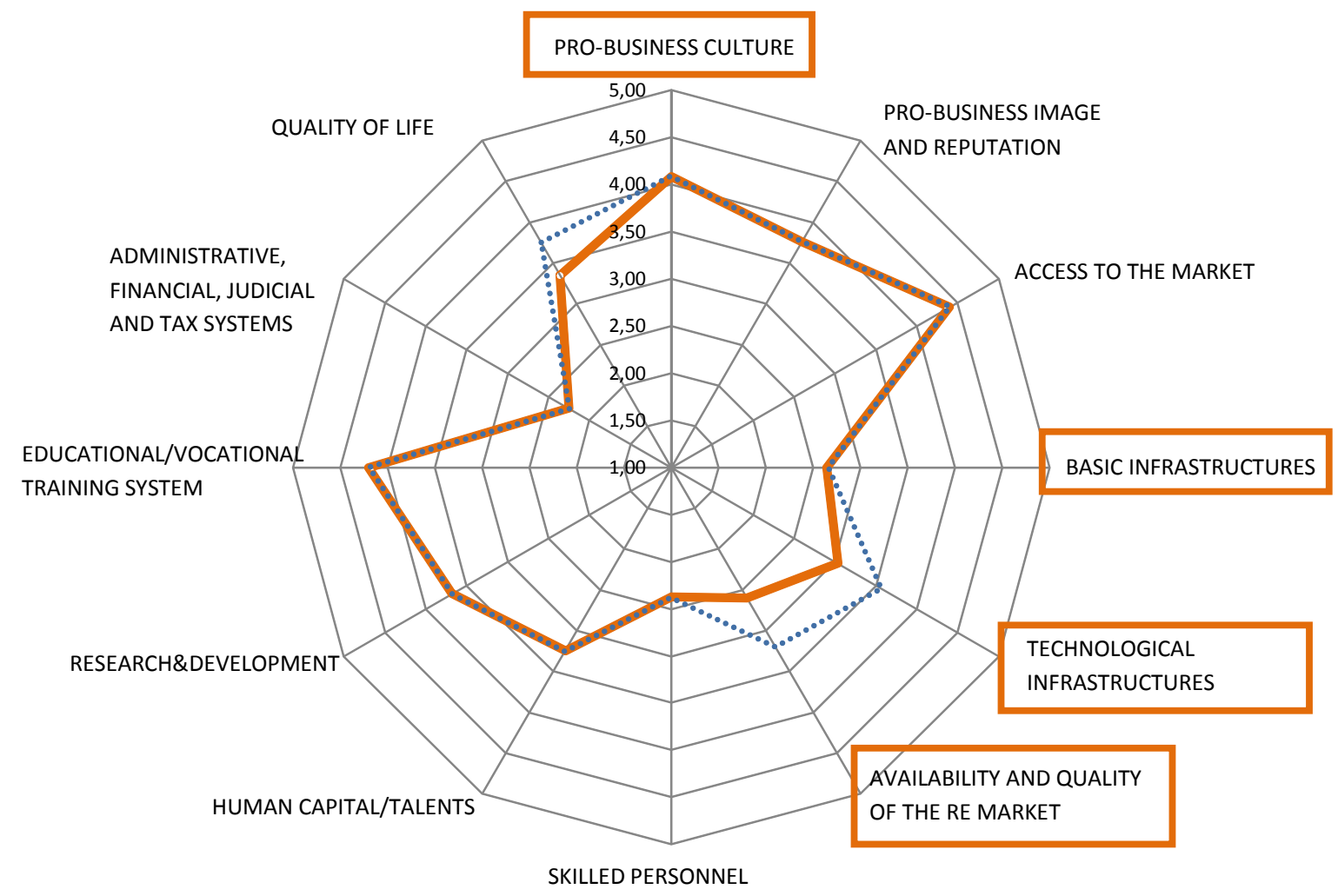

Area of the former Psychiatric Hospital - Limbiate

.... district of $\mathrm{MB}$

Figure 4: Overview radial diagram of the area of Limbiate, a former psychiatric hospital

The analysis of the data reveals that the area of Limbiate is slightly less attractive than the average of the territory of its district, especially regarding technological infrastructures, the availability and the quality of the real estate market, and the quality of life. This can be ascribed to both its location within the district, and its own characteristics. 


\section{OVERVIEW BAR CHARTS OF THE INDICATORS}

In order to get to know the weaknesses of the area that have contributed to lowering the score, the model applies the overview bar charts of the indicators. These show the score given to the specific indicators applied to the area of Limbiate, or those that caused this "adjustment" of the final score.

The analysis of the bar charts is useful to determine which indicators need corrective action to make an area more or less attractive for a specific purpose, and to define the scope for potential improvement while unveiling the criticalities and the potential of the area itself.

\section{Basic infrastructures}

\begin{tabular}{l|c} 
Airport connections & 2.88 \\
\hline Low-cost airport connections & 3.25 \\
\hline Railway connections & 2.50 \\
\hline Road connections & 4.00 \\
\hline Public transportation means & 2.88 \\
\hline Direct connection with the Milan underground & 1.00 \\
\hline Connection with the Central Railway Station of Milan & 2.00 \\
\hline
\end{tabular}

\section{BASIC INFRASTRUCTURES}

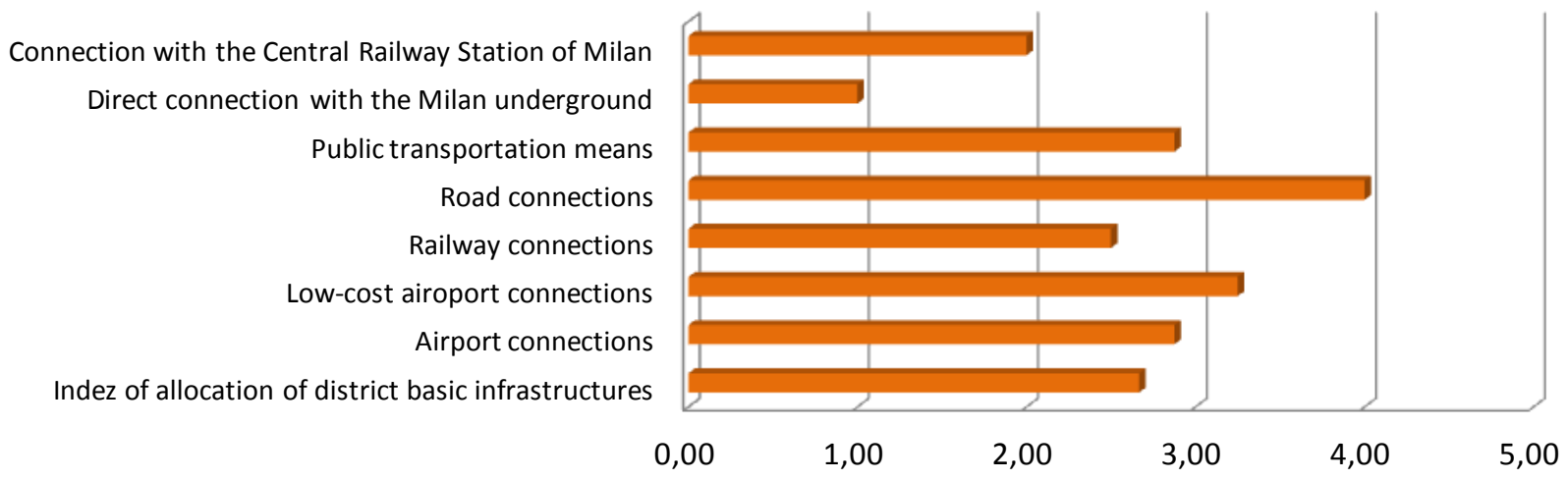

Figure 5: Scores given to the specific indicators picked out for the "Basic infrastructures" factor 


\section{Technological infrastructures}

Broadband availability

Travelling time to the Technology Parks

Availability of tourist-accommodation facilities

TECHNOLOGICAL INFRASTRUCTURES

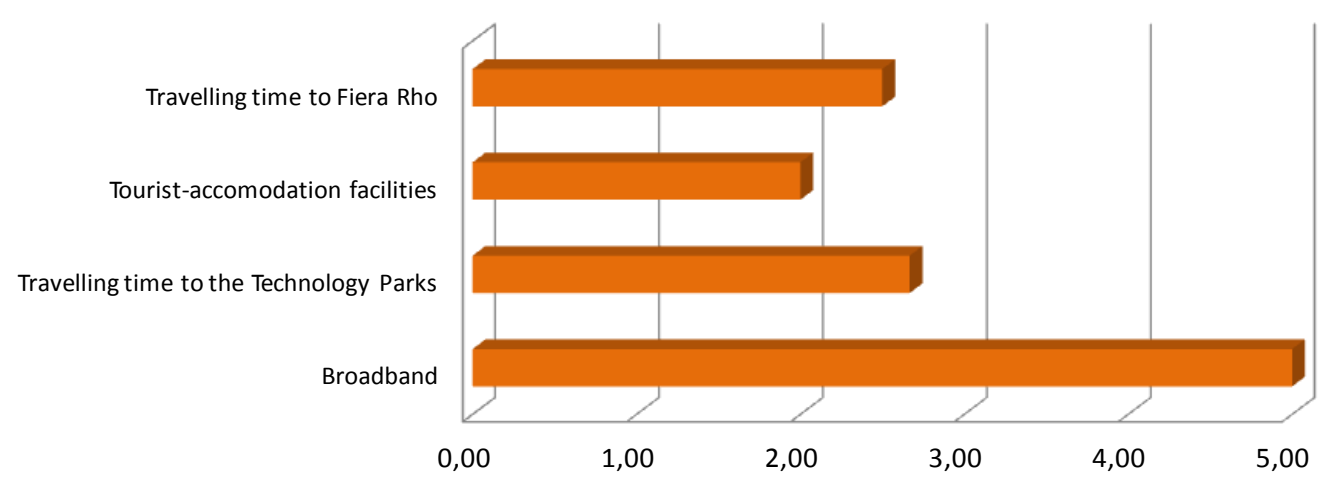

Figure 6: Scores given to the specific indicators picked out for the "Technological infrastructures" factor

\section{Availability and quality of the RE market}

\begin{tabular}{l|l} 
Property values & 3.58 \\
\hline Charges for primary urbanization works & 3.83 \\
\hline Charges for secondary urbanization works & 3.60 \\
\hline Characteristics of the buildings in the area & 1.00 \\
\hline Soil remediation, if any & 1.00
\end{tabular}

\section{AVAILABILITY AND QUALITY OF THE REAL-ESTATE MARKET}

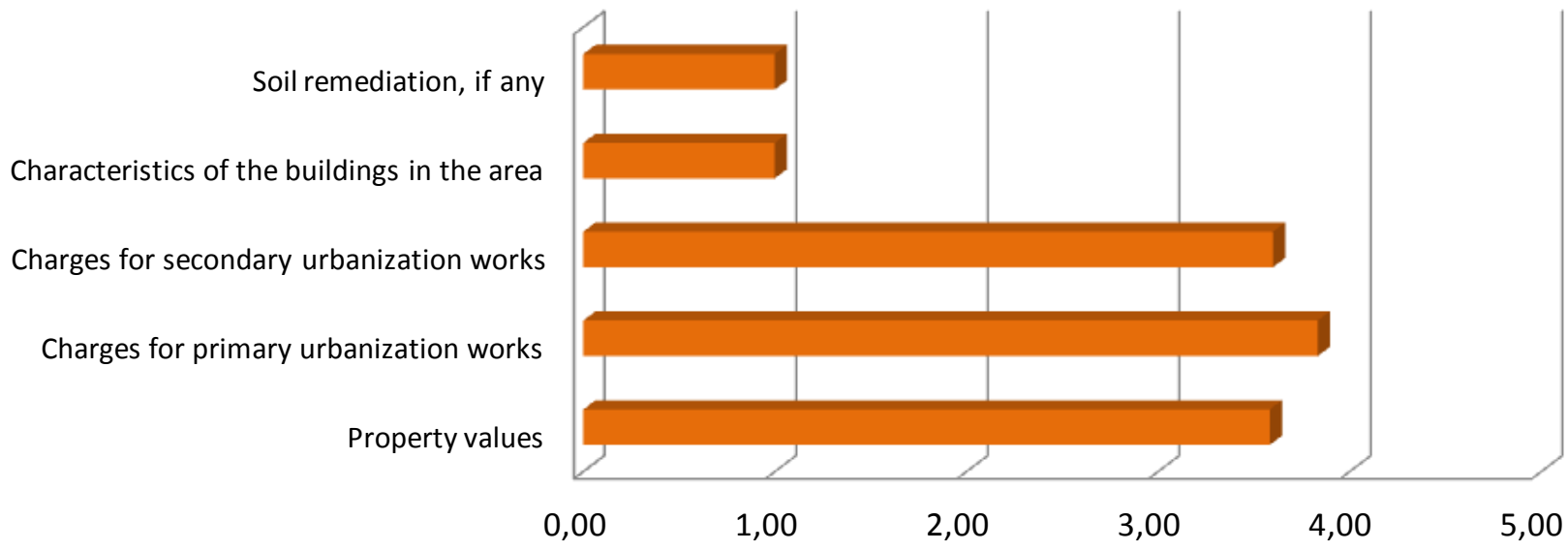

Figure 7: Scores given to the specific indicators picked out for the "Availability and quality of the RE market" factor 


\section{Quality of life}

Travelling distance to the closest hospital (Ospedale di Monza)

Closeness to parks of national appeal

4.00

Travelling distance to downtown Milan

3.00

Travelling distance to the national motor-racing circuit of Monza

3.75

Number of cars / 1000 inhabitants

3.00

3.00

\section{QUALITY OF LIFE}

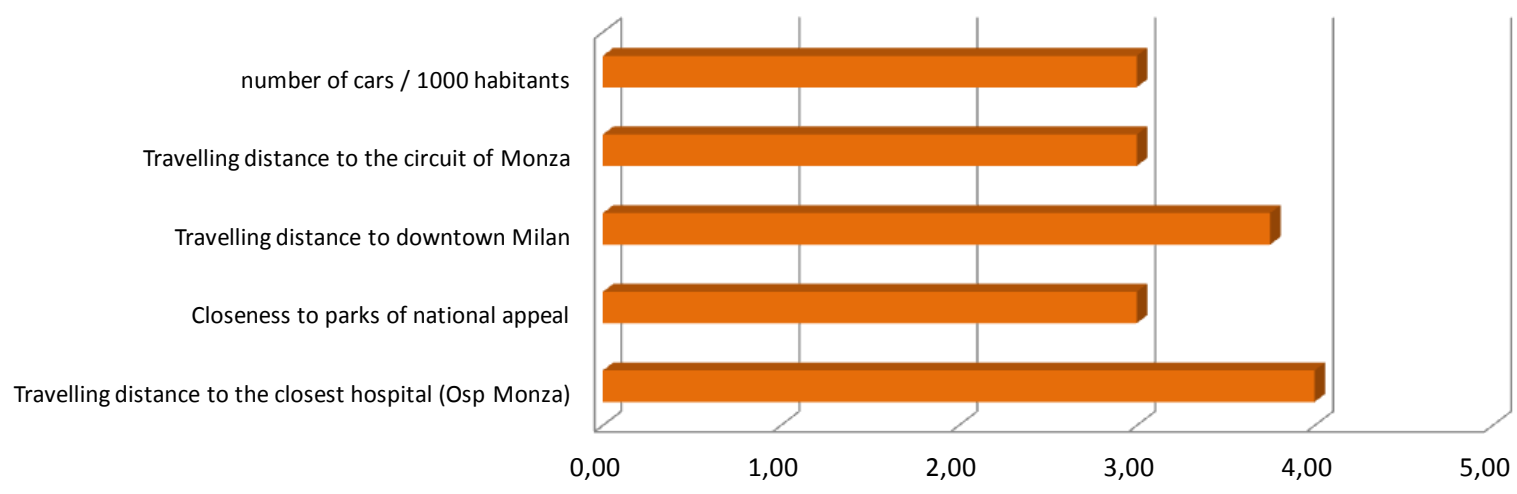

Figure 8: Scores given to the specific indicators picked out for the "QoL" factor

\section{RESULTS OVERVIEW: COMPARING THE AREAS}

Following the application of the model to the three areas examined in the District of Monza and Brianza, we may now collate directly the scores given to the three areas under examination and to the district itself, even by means of a single comparison chart (Figures 9 and 10).

\begin{tabular}{|c|c|c|c|c|}
\hline & \multicolumn{3}{|c|}{ AREA } & \multirow{2}{*}{$\begin{array}{c}\text { District of } \\
\text { Monza and } \\
\text { Brianza }\end{array}$} \\
\hline & $\begin{array}{c}\text { Former San } \\
\text { Gerardo Hospital - } \\
\text { Monza }\end{array}$ & $\begin{array}{c}\text { Former Public } \\
\text { Hospital - Vimercate }\end{array}$ & $\begin{array}{l}\text { Former Psychiatric } \\
\text { Hospital - Limbiate }\end{array}$ & \\
\hline Pro-business culture & 4.08 & 4.08 & 4.08 & 4.08 \\
\hline $\begin{array}{l}\text { Pro-business image and } \\
\text { reputation }\end{array}$ & 3.76 & 3.76 & 3.76 & 3.76 \\
\hline Access to the market & 4.40 & 4.40 & 4.40 & 4.40 \\
\hline Basic infrastructures & 4.13 & 3.38 & 2.64 & 2.67 \\
\hline Technological infrastructures & 3.79 & 3.33 & 3.04 & 3.56 \\
\hline $\begin{array}{l}\text { Availability and quality of the RE } \\
\text { market }\end{array}$ & 2.11 & 2.37 & 2.60 & 3.20 \\
\hline Skilled personnel & 2.38 & 2.38 & 2.38 & 2.38 \\
\hline Human capital/talents & 3.25 & 3.25 & 3.25 & 3.25 \\
\hline Research \& Development & 3.68 & 3.68 & 3.68 & 3.68 \\
\hline Educational and vocational & 4.20 & 4.20 & 4.20 & 4.20 \\
\hline
\end{tabular}




\begin{tabular}{|l|c|c|c|c|}
\hline training system & & & & \\
\hline $\begin{array}{l}\text { Administrative, financial, judicial } \\
\text { and taxation systems }\end{array}$ & 2.25 & 2.25 & 2.25 & 2.25 \\
\hline Quality of life & 3.63 & 3.50 & 3.35 & 3.75 \\
\hline
\end{tabular}

Table IX: Direct comparison among the areas and the District of Monza and Brianza

This stage proves particularly useful to understand the likely vocation of an area as against the other available areas, since it summarises a wealth of information that would otherwise look too complex.

If we hypothesise that an investor has decided to locate his/her business in the District of Monza and Brianza, these charts allow identify which area gets closer to the characteristics sought for among the available areas on the chosen territory.

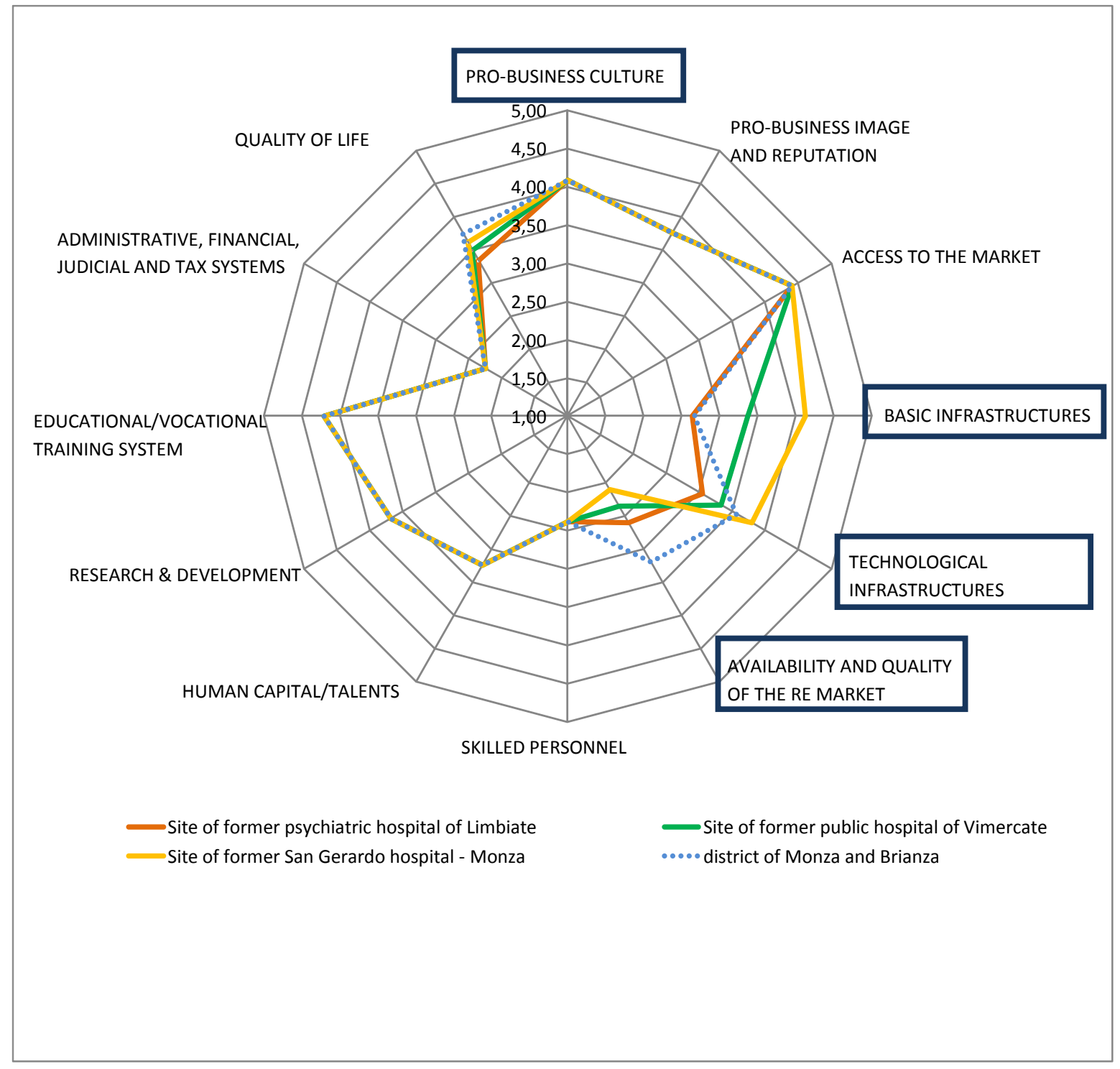

Figure 9: Direct comparison among the three areas and the District of Monza and Brianza 


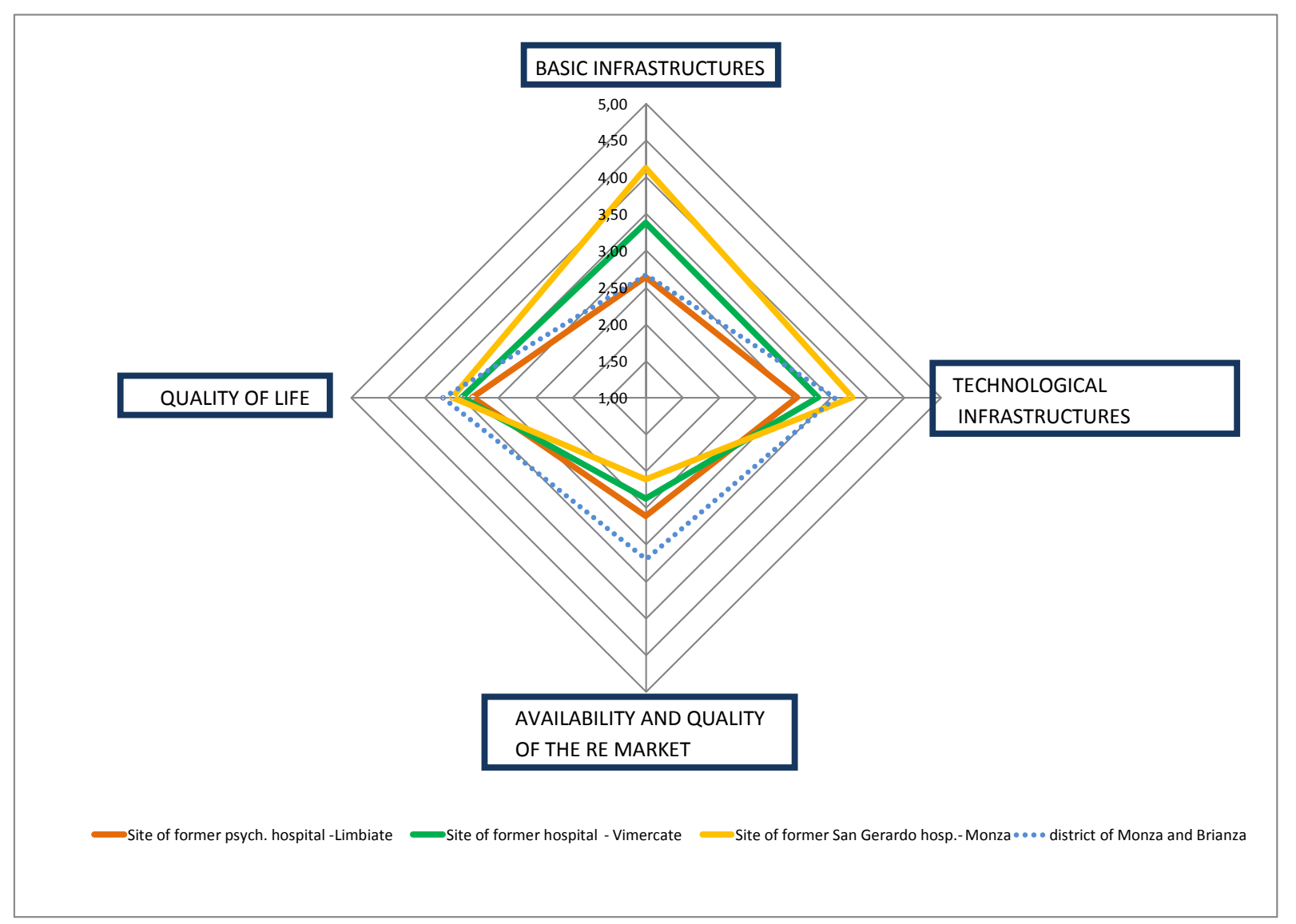

Figure 10: Direct comparison among the three areas and the Province of Monza and Brianza: focus on the 4 key factors

\section{CONCLUSIONS}

The global widening of the location horizons of enterprises is stimulating various Countries and territories to compete in order to attract and preserve productive investments which, in their turn, produce higher employment, higher local incomes and general support to the development processes that affect the territory (Baiardi, L., Morena, M., 2009).

Some industry surveys have revealed that the decisive elements - past and present - in this process are globalization, or the dissemination of the market economy worldwide that has deeply changed the structure of international trade; the scientific and technological developments and their consequences in the fields of technology, communications and information (ICT); and lastly the rising of emerging markets with a huge potential.

This spurred enterprises to raise their internationalization status and to steer their business towards the foreign markets as well, definitively influencing the criteria that underpin the choice of a location. When an enterprise decides to base its business in another country, it has to find out which markets can truly guarantee the most favourable conditions for its investments.

The surveys analysed when producing this paper highlighted the presence of internationally renowned and shared factors that the enterprises generally take into consideration in their decision-making process, and which strongly influence the decision to locate a business in a territory to the detriment of another.

By adopting and organizing these "key factors" in a systemic way, the model introduced in this paper supports enterprises in their location choice. It analyses and measures some territorial contexts (with no limits regarding their size) based on the scores assigned to these contexts after the analysis of the 12 key factors.

A survey was made on three sample areas in the district of Monza and Brianza, which details how the valuation method works and which results emerged from the analysis of one such area and from the comparison of the results reaped from all three areas.

The analysis had two outputs: on the one hand, its results allowed to check whether the areas are actually in line with the expectations and with the requirements of a potential investor, with reference to the activity that such investor is 
willing to promote; on the other, the identification of the characteristics of the area provides the basis to define the vocation of the areas under examination, thus helping the drawing of future development scenarios.

\section{REFERENCES}

AA.W. (2011), L'efficienza dei processi concessori. Con approfondimenti dedicati alla Regione Lombardia e alle strutture sturistico-ricettive. Osservatorio Permanente sulla Pubblica Amministrazione Locale. Milano: II Sole 24 Ore.

Anholt, S., (2007), L'identità competitiva. II branding di nazioni, città,regioni, Milano: Egea;

Baiardi, L., Morena, M., (2009), Marketing territoriale. Milano: II Sole 24 Ore.

Basile, R., Benfratello, L., Castellani ,D., (2008), Le determinanti della localizzazione delle imprese multinazionali: l'attrattività dell'Italia nel contesto europe. In: L., Rondi, F., Silva (a cura di), Prove di cambiamento nel sistema produttivo italiano. Milano: II Mulino.

Brambilla M., Come attrarre investimenti e trattenere i talenti. Italiafutura, luglio, 2011.

Caroli, M. G., (2001), Globalizzazione e localizzazione dell'impresa internazionalizzata. Milano: Franco Angeli.

CONFINDUSTRIA, (2010), Italia 2015. Le imprese per la modernizzazione del Paese.

CONFINDUSTRIA, (2011), La localizzazione delle imprese multinazionali in Europa: perché cosi poche in Italia?.

Coughlin, C. C., Terza, J. V, Aromdee, V. (1991), State Characteristics and the Location of Foreign Direct Investment within the United States. In "The Review of Economics and Statistics", n. 73, pp.675-683.

Cushman \& Wakefield, (2012), European Cities Monitor. 23a Edizione.

Del Colle, E., (2006), Tecnopoli. L'articolazione territoriale della competitività in Italia. Milano: Franco Angeli.

Di Savino, C., (2007), Marketing territoriale. Milano: Franco Angeli.

Ernst \& Young, (2012), Growth, actually. European Attractiveness Survey (EAS).

Ernst \& Young (2010), European Investment Monitor (EIM).

European Commission, Joint Research Centre EU, (2010), Regional Competitiveness Index.

Florida, R., (2003), L'ascesa della nuova classe creativa. Stili di vita, valori e professioni. Milano: Mondadori.

Lane, J. E., (2000), The Public Sector: Concepts, Models and Approaches, London: SAGE Publications;

Latusi, S., (2002), Marketing territoriale per gli investimenti. Milano: Egea;

Micossi, S., (1997), La via dell'Unione Europea verso un sistema commerciale globale e aperto. in M., Arcelli, (a cura di), Globalizzazione dei mercati e orizzonti del capitalismo, Roma-Bari: Ed. Laterza.

OCSE, (2002), Foreign Direct Investment for Development: Maximising Benefits, Minimising Costs.

Porter, M. E., (1990a), The Competitive Advantage of Nations. New York: Free Press, MacMillan.

Saaty, T. L., (1994), Foundamentals of Decision Making and Priority Theory with the Analytical Hierarchy Process. Pittsburgh: RWS Pubblications;

Sassen, S., (2008), A sociology of globalization - Una sociologia della globalizzazione. Torino: Edizioni Einaudi.

Siemens Ambrosetti (2007), Investimenti esteri in Italia, Milano;

World Economic Forum, Global Competitiveness Report 2009/2010 